\title{
In-Vitro effect of Ficus deltoidea on the contraction of isolated rat's uteri is mediated via multiple receptors binding and is dependent on extracellular calcium
}

\author{
Naguib Salleh ${ }^{*}$ and Vivi Noryati Ahmad
}

\begin{abstract}
Background: Ficus deltoidea, is a perennial herb that is used to assist labor, firm the uterus post-delivery and to prevent postpartum bleeding. In view of its claimed uterotonic action, the mechanisms underlying plant's effect on uterine contraction were investigated.

Methods: Adult female SD rats were injected with $2 \mathrm{mg} / \mathrm{kg} 17 \beta$-oestradiol $\left(E_{2}\right)$ to synchronize their oestrous cycle. A day after injection, uteri were removed for in-vitro contraction studies. The dose dependent effect of Ficus deltoidea aqeous extract (FDA) on the tension produced by the isolated rat's uteri was determined. The effects of atropine

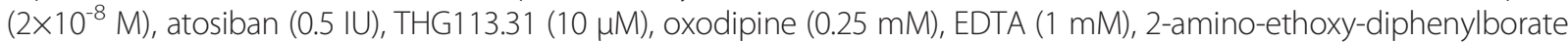
(2-APB) $(40 \mathrm{mM})$ and thapsigargin $(1 \mathrm{mM})$ on the maximum force of contraction (Emax) achieved following $2 \mathrm{mg} / \mathrm{ml}$ FDA administration were also investigated.

Results: FDA induced in-vitro contraction of the isolated rat's uteri in a dose-dependent manner. Administration of atropine, atosiban and THG113.31 reduced the Emax with atosiban having the greatest effect. The Emax was also reduced following oxodipine and EDTA administration. There was no significant change observed following 2-APB administration. Thapsigargin, however, augmented Emax.

Conclusions: FDA-induced contraction of the isolated rat's uteri is mediated via multiple uterotonin receptors (muscarinic, oxytocin and prostaglandin F2a) and was dependent on the extracellular $\mathrm{Ca}^{2+}$. Contraction, however, was not dependent on the $\mathrm{Ca}^{2+}$ release from the internal stores. This in-vitro study provides the first scientific evidence on the claimed effect of Ficus Deltoidea on uterine contraction.
\end{abstract}

Keywords: Ficus deltoidea, Uterotonin receptors, Extracellular $\mathrm{Ca}^{2+}$

\section{Background}

Uterotonic plants, are plants that stimulate uterine contraction and have been used since the ancient times to assist labor, remove the retained placenta, treat post partum bleeding and as an abortifacient [1]. Despite their use, scientific evidence to substantiate their beneficial effects are still being explored Several plant extracts have been reported to induce uterine contraction which include the leaves extract of P. nigrescens, $C$. bonduc and A. africanus

\footnotetext{
* Correspondence: naguib.salleh@yahoo.com.my

Department of Physiology, Faculty of Medicine, University of Malaya, Lembah Pantai, Kuala Lumpur 50603, Malaysia
}

\section{Ciomed Central}

(c) 2013 Salleh and Ahmad; licensee BioMed Central Ltd. This is an open access article distributed under the terms of the Creative Commons Attribution License (http://creativecommons.org/licenses/by/2.0), which permits unrestricted use, distribution, and reproduction in any medium, provided the original work is properly cited.

\section{several other extracts from various plant species $[8,9]$.}

One of the plants that is popularly used among the Southeast Asian women to induce uterine contraction is Ficus deltoidea, which belongs to the family Moraceae [10]. Ficus deltoidea has been claimed to possess uterotonic properties that can assist labor as well as can promote involution of the uterus, cervix and vagina during the postpartum period. In addition, it has also been used to treat abnormalities in the menstrual cycle and for birth spacing purposes. Ficus deltoidea is a small perennial herb which rarely exceeds 2 meters in height and is domestically cultivated. It is known by various names such as Mas 
Cotek in Malaysia, Tabat Barito in Indonesia, Agoluran in The Philippines and Kangkalibang in Africa [11]. Different sub-species can be identified based on the leaf shape; with the female plants possessing larger and more round leaves, whereas the males are smaller with long and round leaves [12]. All parts of this plant are medicinally useful. The leaves (when boiled), stems, roots and fruits are traditionally use to treat arthritis, boost the immune system and increase the sexual desire [13]. Additionally, the leaves are also claimed to be a powerful fat burner, help to decrease plasma cholesterol level and are experimentally proven to lower the blood glucose level [14]. Recently, the fruit extract of Ficus deltoidea was found to possess antidiabetic and antioxidant properties [15].

The notion that Ficus deltoidea affects uterine contraction was based on several previous studies involving other Ficus species which also indicate their effect on the uterine contractility. Most of these studies were conducted in-vitro using isolated uteri from rodents. Bafor et al. [16] conducted an in-vitro study using isolated strips of mouse uteri to investigate the effect of the active constituent of Ficus exasperata leaf extract on uterine contraction. They have found that metabolites generated from this extract possess both tocolytic and uterotonic activities. Earlier, in-vitro contraction studies using isolated rat's uteri revealed both stimulatory [17] and inhibitory [18] effects of the unpurified extract of Ficus exasperata. Further to this, Watcho et al., [1] demonstrated that fruit extract of Ficus asperifolia stimulates in-vitro contraction of the uteri isolated from oestrogenized rats. Another Ficus species, Ficus capensis was shown to inhibit in-vitro contraction also in the isolated rat's uteri [19]. In view of the fact that Ficus species was found to affect uterine contractility, we hypothesized that Ficus deltoidea, which is also from the Moraceae family, may affect uterine contraction as traditionally claimed. Therefore, using similar experimental model $[1,17,18,20]$, we investigated Ficus Deltoidea effect on uterine contraction.

\section{Methods}

\section{Preparation of $F$. Deltoidea Aqeous extract (FDA)}

Leaves of $F$ deltoidea from female sub-species used in this study were supplied by Delto Medicama Plantation, Kuala Selangor, Malaysia. The plant sample was deposited at the Herbarium in Rimba Ilmu, University of Malaya, Kuala Lumpur for authentication and identification purposes with Herbarium number: KLU 46469. The leaves were air-dried, cut into small pieces and grounded into powder form. Each of the pulverized parts were weighed (100 grams) and boiled twice in 1 litre distilled water for 4 hours. The aqueous extract was then concentrated by heating at $60^{\circ} \mathrm{C}$ and was later subjected to freeze- drying (yield $7.36 \%$ and $11.61 \% \mathrm{w} / \mathrm{w}$, dry weight basis for leaf) and was stored in a container until further use. Stock solution was obtained by dissolving small aliquots of this extract in water.

\section{Uterine tissue preparation and In-Vitro contraction study}

Adult female Wistar Kyoto (WKY) rats weighing 250 grams were purchased from the Animal House, Faculty of Medicine, University of Malaya, Kuala Lumpur. The rats were housed in a controlled environment with temperature kept at $25^{\circ} \mathrm{C}$, relative humidity between $30-70 \%, 12$ hours light-dark cycle and had free access to rodent food pellet and tap water ad libitum. Cleanliness of the housing environment was maintained daily. Shredded recycled paper was used as bedding. Each group consists of six rats $(n=6)$. All experimental procedures were approved by the University of Malaya Medical Center Animal Ethics Committee (Ethics Reference No: FIS/ 01/12/2008/ NS (R)). Intact, non-ovariectomised female WKY rats were treated with high dose of $E_{2}$ at $2 \mathrm{mg} / \mathrm{kg} /$ day to synchronize their oestrous cycle [17]. A day after injection, the rats were humanely sacrificed and the uteri were immediately removed and placed into a physiological solution. The tissue was then placed vertically in an organ bath containing solution with the following electrolytes composition: $\mathrm{NaCl}(155 \mathrm{mM}), \mathrm{KCl}(4.5 \mathrm{mM}), \mathrm{MgCl}_{2}(1.0 \mathrm{mM})$, $\mathrm{CaCl}_{2}(2.0 \mathrm{mM})$ and $\mathrm{D}$ - glucose $(10 \mathrm{mM})$ while the $\mathrm{pH}$ was maintain at 7.40 with $\mathrm{NaOH}$. The temperature of the organ bath was maintained at $37^{\circ} \mathrm{C} .95 \% \mathrm{O}_{2}$ and $5 \% \mathrm{CO}_{2}$ was continuously delivered into the bathing solution. Each uterine strip was placed under optimum resting force of $1 \mathrm{~g}$ and was allowed to equilibrate for 30 minutes prior to drug administration. During this period, the strips were washed with $10 \mathrm{ml}$ fresh physiological solution every 15 minutes according to the method by Oropeza et al., [21]. Each experiment was repeated six times using new uterine strips from different rats $(n=6)$. Contractile forces were recorded isometrically by a force transducer which was connected to a bridge amplifier and to the PowerLab data acquisition system (ADI Instrument, Australia).

FDA was added in a dose-dependent manner (0.125$4.0 \mathrm{mg} / \mathrm{ml}$ ) and the dose- response effect was then recorded. Preliminary investigation revealed that $1 \times 10^{-2} \mathrm{M}$ Ach (Sigma-Aldrich), 7 I.U. oxytocin (Sigma-Aldrich) and $5 \mu \mathrm{g} / \mathrm{ml}$ PGF2 $\alpha$ (Sigma-Aldrich) produced maximum force of contraction (Emax), which values differ between the respective agonists. Meanwhile, $2 \mathrm{mg} / \mathrm{ml}$ FDA also resulted in maximum contraction (Emax), however with a lower Emax than other tested agonists. Atropine (Sigma-Aldrich) $\left(2 \times 10^{-8} \mathrm{M}\right)$, a muscarinic receptor antagonist; atosiban (Fluka Co) (0.5 IU), an oxytocin receptor antagonist, THG113.31 (Theratechnologies) $(10 \mu \mathrm{g} / \mathrm{ml})$, a PGF2 $\alpha$ receptor antagonist, oxodipine (Sigma-Aldrich) $(0.25 \mu \mathrm{M})$, an L-type $\mathrm{Ca}^{2+}$-channel blocker, 2-APB (Sigma 
Aldrich) $(40 \mu \mathrm{M})$, an $\mathrm{IP}_{3}$ receptor $\left(\mathrm{IP}_{3} \mathrm{R}\right)$ blocker, thapsigargin (Sigma Aldrich) $(1 \mu \mathrm{M})$, a sarcoplasmic reticulum $\mathrm{Ca}^{2+}$-ATPase (SERCA) inhibitor and EDTA (Sigma Aldrich) (1 $\mathrm{mM})$, a $\mathrm{Ca}^{2+}$ chelator were administered to investigate the mechanism underlying FDA effect on uterine contraction. In order to observe the effect of these inhibitors, $2 \mathrm{mg} / \mathrm{ml}$ FDA was initially added into the bathing solution and once contraction was stable at Emax, these inhibitors were either individually or simultaneously added and their effects on the Emax were then recorded.

\section{Statistical analysis}

Results were expressed as mean \pm SEM. Data was analyzed using Student's $t$ - test. $\mathrm{p}<0.05$ was considered to be statistically significant.

\section{Results}

Dose-dependent effect of FDA on uterine contraction In Figure 1, the force of contraction increases with increasing doses of FDA. In the control group, the force recorded was $0.5 \pm 0.05 \mathrm{~g}$ tension, which was the baseline contraction in oestrogenized rats' uteri. At $0.25 \mathrm{mg} / \mathrm{ml}$, the force generated was 2.4 times greater than the control. Meanwhile, the forces increase by 3.0, 4.1 and 4.9 times following administration of $0.5,1$ and $2 \mathrm{mg} / \mathrm{ml}$ FDA respectively with $2 \mathrm{mg} / \mathrm{ml}$ FDA produced the maximum tension (Emax).

\section{Effect of atropine, THG113.31 and atosiban on the Emax induced by $2 \mathrm{mg} / \mathrm{ml} \mathrm{FDA}$}

In Figure 2, administration of muscarinic receptor antagonist, atropine, into the bathing solution containing isolated uterine tissue pre-exposed to $2 \mathrm{mg} / \mathrm{ml}$ FDA resulted in the Emax to decrease by 1.19 times. Meanwhile, administration of THG113.31, a non-competitive inhibitor for PGF2 $\alpha$ receptor, as well as atosiban, an oxytocin receptor blocker resulted in the Emax to also decrease by 1.32 and1.60 times respectively. Simultaneous administration of atropine, atosiban and THG113.31 resulted in 4.45 times decrease in Emax as compared to $2 \mathrm{mg} / \mathrm{ml}$ FDA administration alone.

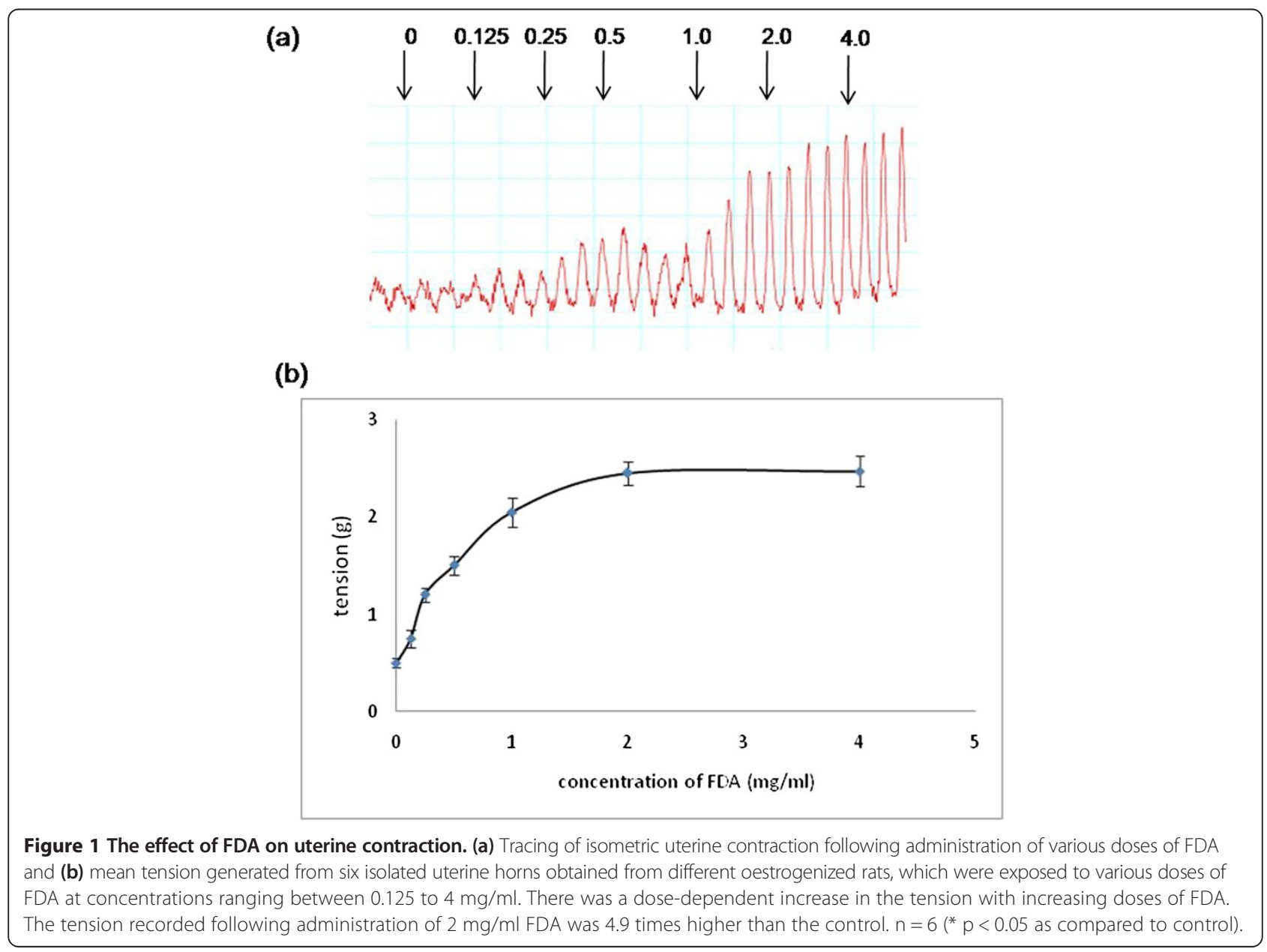


(a)

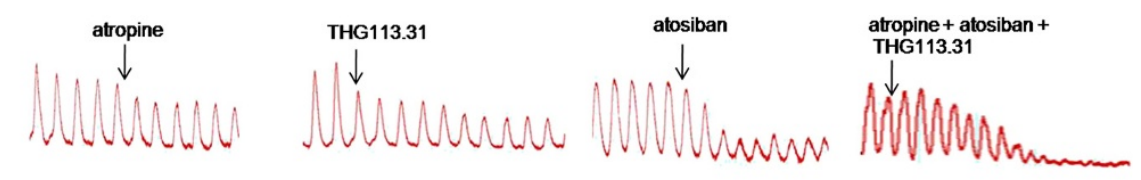

(b)

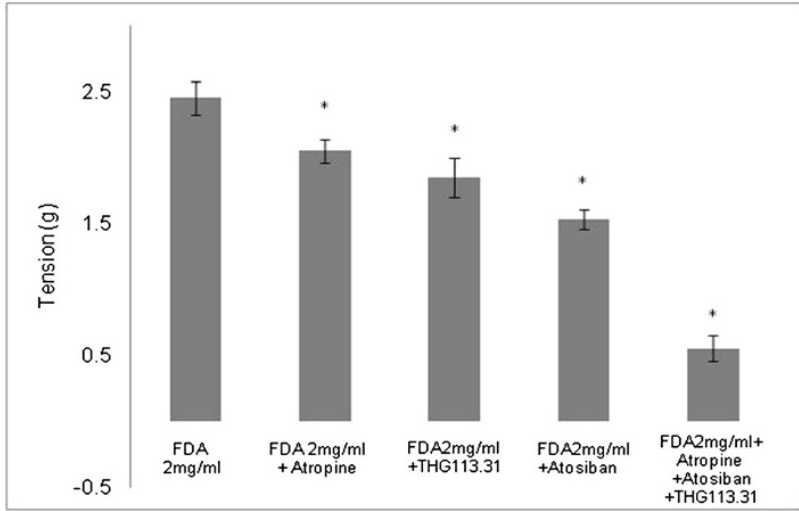

Figure 2 The effect of selected receptor antagonists on FDA-induced uterine contraction. (a) Representative tracings of isometric uterine contraction following FDA administration in the presence of various antagonists and (b) mean Emax following administration of FDA at 2 mg/ml and in the presence of atropine, THG1 13.31 and atosiban. Atropine caused the least inhibition while atosiban produced the greatest inhibition on the Emax. Concomitant administration of all three antagonists resulted in a remarkable decrease in the Emax. $n=6$ rats per group, ${ }^{*} p<0.05$.

\section{Relative potency of FDA as uterotonin}

In Table 1, the relative potency of FDA was compared to other uterotonins. The Emax produced following administration of $2 \mathrm{mg} / \mathrm{ml}$ FDA was $2.45 \pm 0.10 \mathrm{~g}$. Meanwhile, the Emax produced following administration of $1 \times 10^{-2} \mathrm{M}$ Ach, 7 I.U oxytocin and $5 \mu \mathrm{g} / \mathrm{ml}$ PGF2 $\alpha$ were $2.98 \pm 0.25$, $3.51 \pm 0.47$ and $3.43 \pm 0.19$ g respectively.

\section{Effect of oxodipine and EDTA on the Emax induced by $2 \mathrm{mg} / \mathrm{ml}$ FDA}

In Figure 3, administration of oxodipine, a voltage-gated L-type $\mathrm{Ca}^{2+}$ channel antagonist into the bathing solution containing isolated uterine tissue pre-exposed to $2 \mathrm{mg} / \mathrm{ml}$ FDA resulted in the Emax to decrease by $88.5 \%$. Meanwhile, administration of EDTA into this solution which resulted in depletion of extracellular $\mathrm{Ca}^{2+}$ caused the Emax to decrease by a greater percentage (96.8\%). Lesser degree of inhibition by oxodipine and EDTA in isolated uterine tissue pre-exposed to oxytocin indicated that this effect of oxytocin was not solely dependent on the extracellular $\mathrm{Ca}^{2+}$.

Table 1 Relative potency of FDA as compared to other uterotonins

\begin{tabular}{lc}
\hline & Tension $\mathbf{( g )}$ \\
\hline FDA & $2.45 \pm 0.10$ \\
Acetylcoline (Ach) & $2.98 \pm 0.25$ \\
Oxytocin & $3.51 \pm 0.27$ \\
Prostaglandin F2a (PGF2a) & $3.43 \pm 0.19$ \\
\hline
\end{tabular}

FDA is 1.43 times less potent than oxytocin. This extract is also 1.40 and 1.21 times less potent than PGF2 $a$ and Ach respectively. $n=6$ per treatment group.
Effect of 2-APB and thapsigargin on the Emax induced by $2 \mathrm{mg} / \mathrm{ml}$ FDA

In Figure 4, administration of 2-APB, an IP3R blocker into the bathing solution containing isolated uterine tissue pre-exposed to $2 \mathrm{mg} / \mathrm{ml}$ FDA did not cause any significant changes in the Emax produced. Meanwhile, administration of SERCA inhibitor, thapsigargin, resulted in $8.5 \%$ increase in the Emax as compared to FDA alone. 2-APB caused a significant decrease in the Emax in isolated uterine tissue pre-exposed to oxytocin, while thapsigargin administration resulted in the opposite effect.

\section{Discussion}

To the best of our knowledge, this study is the first to display uterotonic effect of Ficus deltoidea, which justifies the claim that this plant assists in uterine contraction. We have shown that FDA effect is mediated via muscarinic, oxytocin and PGF2 $\alpha$ receptors and is dependent on the extracellular $\mathrm{Ca}^{2+}$. These mechanisms were confirmed from inhibition of the maximum tension (Emax) produced by $2 \mathrm{mg} / \mathrm{ml}$ FDA following administration of the antagonists to these receptors and inhibitors to the $\mathrm{Ca}^{2+}$ channels. FDA is 1.43 times less potent than oxytocin, which is a gold standard uterotonin [15]. Apart from Ficus deltoidea, a few other Ficus species including Ficus exasperata [17,22] and Ficus asperifolia [1] were also reported to stimulate uterine contraction, suggesting that uterotonic effect is common to the Ficus species.

Our findings suggested that FDA-induced uterine contraction was mediated mainly via the oxytocin receptor as evidenced by the highest degree of inhibition of the 


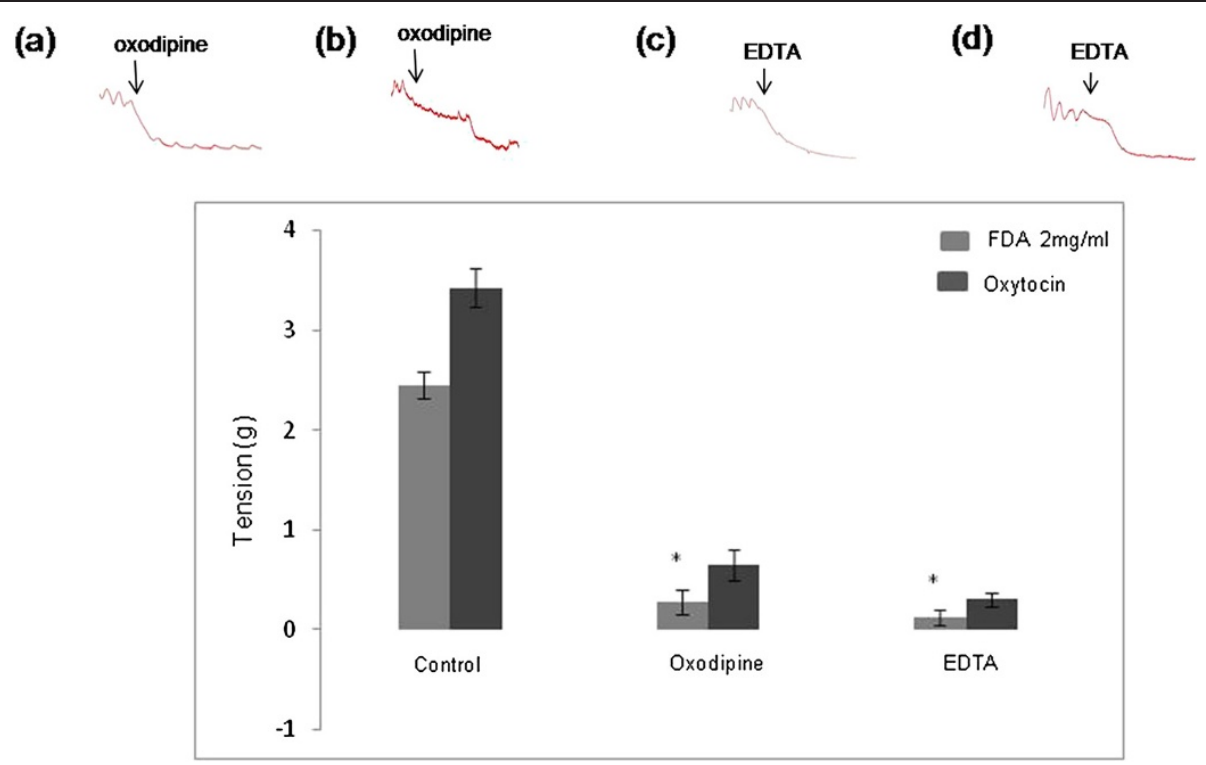

Figure 3 The effect of calcium channel blocker and extracellular calcium removal on FDA-induced uterine contraction. Representative image of isometric uterine contraction following administration of (a) $2 \mathrm{mg} / \mathrm{ml} \mathrm{FDA} \mathrm{plus} \mathrm{oxodipine,} \mathrm{(b)} \mathrm{oxytocin} \mathrm{plus} \mathrm{oxodipine,} \mathrm{(c)} 2 \mathrm{mg} / \mathrm{ml}$ FDA plus EDTA and (d) oxytocin plus EDTA while bar chart shows the Emax following oxodipine and EDTA administration as compared to the control. Contraction was almost abolished following EDTA administration in the isolated uteri pre-exposed to FDA. $n=6\left({ }^{*} p<0.05\right)$.

Emax by atosiban. Moderate inhibition of the Emax by THG113.31 suggested that FDA binding to PGF2 $\alpha$ receptor produced moderate degree of contraction while the lowest inhibition by atropine suggested that FDA binding to the muscarinic receptor produced the least degree of contraction. The cumulative inhibitory effect observed following concomitant administration of atropine,
THG113.31 and atosiban confirmed the involvement of all three receptors in mediating FDA-induced uterine contraction. The presence of muscarinic, oxytocin and PGF2 $\alpha$ receptors in the uterus has been previously reported [23-25]. These receptors were reported to be up-regulated by $\mathrm{E}_{2}$ and in the late pregnancy particularly at term [26]. In view of this, high dose $E_{2}$ administration
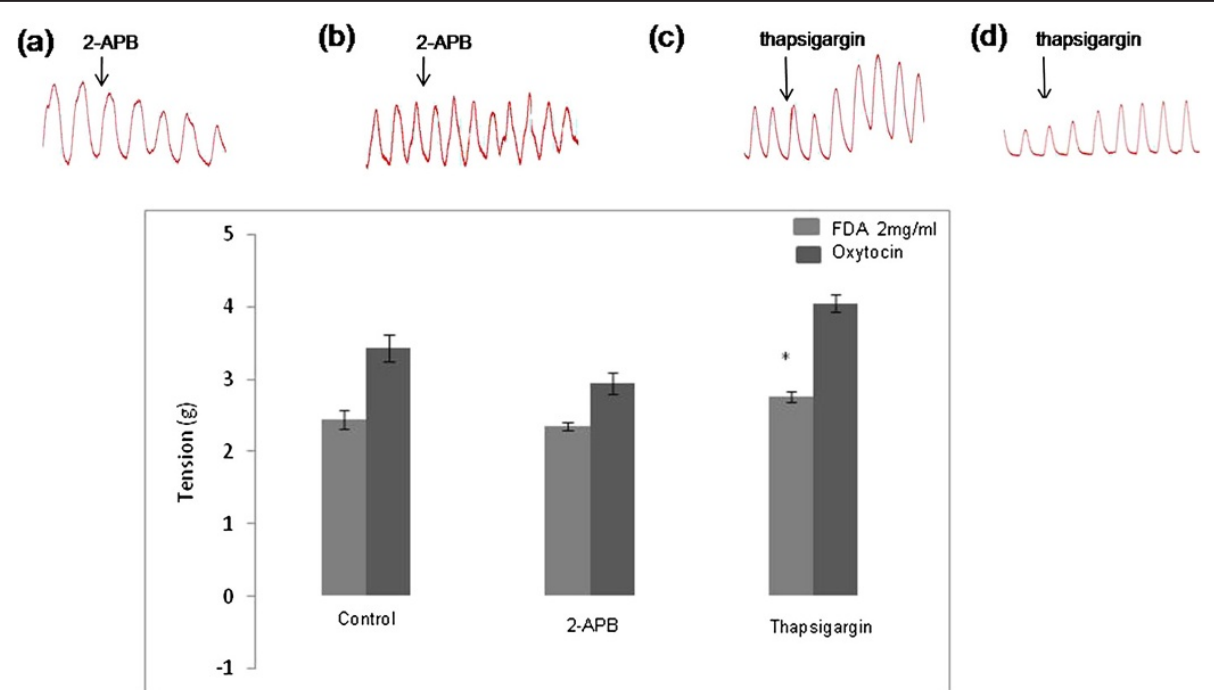

Figure 4 The effect of IP3R blocker and SERCA inhibitor on FDA-induced uterine contraction. Representative image of isometric uterine contraction following administration of (a) oxytocin plus 2-APB, (b) FDA 2 mg/ml plus 2-APB, (c) oxytocin plus thapsigargin and (d) FDA 2 mg/ml plus thapsigargin while bar chart shows the Emax following oxytocin and FDA administration with and without the presence of 2-APB and thapsigargin. No significant difference was noted following 2-APB administration in the FDA treated group while thapsigargin caused a slight but significant increase in the Emax. 
to the rats prior to the experiment can result in an increase in the number of these uterotonin receptors, potentiating the effect of FDA on uterine contraction.

There is a possibility that the greatest effect produced following FDA binding to the oxytocin receptor (as evidenced by the greatest inhibition of the Emax by atosiban) was due to high number of this receptor expression in the uterus. Meanwhile, lesser inhibition by THG113.31 and atropine suggested that the number of PGF2 $\alpha$ and muscarinic receptors expressed was lower than the number of oxytocin receptor expression. Up-regulation of oxytocin receptor by $E_{2}$ and at term [26,27] has been reported in human [28], rat [25] and mouse [29] uterus while muscarinic and PGF2 $\alpha$ receptors expression has also been reported in rat [30-33], rabbit [34] and human [23] uterus which were also being up-regulated by $E_{2}$ [24]. Previous reports also indicate that oxytocin receptor expression in the uterus is the highest [35,36], supporting our observation that FDA effect was mostly mediated via this receptor binding. Apart from the increase in the number of receptors, high affinity FDA binding to the oxytocin receptor may also result in the observed effect. Oxytocin and PGF2 $\alpha$ have been reported to play an important role in the myometrial contraction [37]. Oxytocin-induced myometrial contraction has been shown in estrogen-primed non-pregnant swine uteri $[38,39]$. Activation of the oxytocin and PGF2 $\alpha$ receptors which are coupled to $G$ protein alpha(q) stimulates uterine contraction through activating the phospholipase $\mathrm{C} / \mathrm{Ca}^{2+}$ dependent pathway, while activation of the muscarinic receptor which is coupled to $\mathrm{G}$ protein alpha(i) potentiates contraction through inhibiting the cAMP production [40]. Besides Ficus deltoidea, other Ficus species including Ficus asperifolia has also been reported to induce uterine contraction through binding to the muscarinic, oxytocin and histamine receptors in the uterus [41].

$\mathrm{Ca}^{2+}$, which is essential for smooth muscle contraction [42], can be derived from the intracellular stores and/or extracellular fluid $[42,43]$. Extracellular $\mathrm{Ca}^{2+}$ enters the cell via the voltage-gated dihydropyridine channels at the myocyte plasma membrane [44]. Following the opening of this channel, $\mathrm{Ca}^{2+}$ enters down its concentration gradient. This will then trigger the release of $\mathrm{Ca}^{2+}$ from the intracellular stores [45]. In this study, the involvement of intracellular and extracellular $\mathrm{Ca}^{2+}$ in myometrial contraction was investigated following oxytocin and $2 \mathrm{mg} / \mathrm{ml} \mathrm{FDA}$ administration. Our findings indicate that oxytocin-induced uterine contraction depends mostly on the extracellular $\mathrm{Ca}^{2+}$ while intracellular $\mathrm{Ca}^{2+}$ is also required for contraction. Following binding of oxytocin to its G protein-coupled receptor, phospholipase C (PLC) will be activated which causes an increase in inositol trisphosphate (IP3) and diacylglycerol (DAG) levels. IP3 activates the IP3R receptor at the sarcoplasmic reticulum membrane which causes the release of stored $\mathrm{Ca}^{2+}$ into the cytosol. Increased cytosolic $\mathrm{Ca}^{2+}$ will further induced extracellular $\mathrm{Ca}^{2+}$ influx [42], resulting in a further rise in the intracellular $\mathrm{Ca}^{2+}$ level. $\mathrm{Ca}^{2+}$ will then binds to calmodulin, which activates the myosin light chain kinase leading to phosphorylation of myosin light chains, triggering contraction [46].

A marked decrease in the Emax following oxodipine and EDTA administration suggested the dependency of FDA-induced uterine contraction on the extracellular $\mathrm{Ca}^{2+}$. This could be similar to the contraction induced by wild ginger (Costus speciosus) rhizome [47] and pomegranate (Punica granatum L., Punicaceae) seed [48] extracts which was also shown to solely depend on the extracellular $\mathrm{Ca}^{2+}$. In this study, FDA binding to the muscarinic, oxytocin and PGF2 $\alpha$ receptors may trigger the extracellular $\mathrm{Ca}^{2+}$ influx prior to contraction. Although FDA has been shown to mediate its uterotonic effect, mostly via oxytocin receptor binding, the contraction produced however does not depend on the intracellular $\mathrm{Ca}^{2+}$ as evident from the lack of inhibition on the Emax by 2-APB. This is in contrast to oxytocin-induced uterine contraction, whereby its dependency on the intracellular $\mathrm{Ca}^{2+}$ was evidenced from the inhibition of Emax by 2 -APB. We speculated that the inability of FDA to induce the release of $\mathrm{Ca}^{2+}$ from the internal stores could be due to its inability to provide adequate stimulus to trigger the intracellular cascade leading to the release of $\mathrm{Ca}^{2+}$ from the intracellular stores, despite of its binding to the oxytocin receptor. On the other hand, FDA may also bind at lower affinity to other uterotonin receptors, which may explain lesser potency of FDA as uterotonin as compared to oxytocin, PGF2 $\alpha$ and Ach.

In addition to the binding to the oxytocin receptor, FDA-induced extracellular $\mathrm{Ca}^{2+}$ influx could also involve other agonists' receptor binding. This includes the PGF2 $\alpha$ receptor; which was found to mediate uterine contraction in the laying hens via inducing the influx of extracellular $\mathrm{Ca}^{2+}$ [49]. Our finding has shown that administration of thapsigargin, a SERCA inhibitor resulted in a slight but significant increase in the Emax induced by oxytocin and FDA. This effect could be due to the depletion of stored $\mathrm{Ca}^{2+}$ by thapsigargin which inhibit the reuptake of cytosolic $\mathrm{Ca}^{2+}$ into the sarcoplasmic reticulum. The consistently high cytosolic $\mathrm{Ca}^{2+}$ will activate extracellular $\mathrm{Ca}^{2+}$ entry which would further enhance uterine smooth muscle contraction [50].

\section{Conclusion}

Using in-vitro model, our study has provided the first scientific evidence to support the claim that Ficus deltoidea stimulates uterine contraction. The active compound that is responsible in mediating this effect is currently 
unknown, although Ficus deltoidea has been reported to contain flavonoids isovitexin, vitexin [51], proantrocyanidins, flavan-3-ol monomer and flavones glycosides [52]. Phytochemical analyses further revealed the presence of tannins, tripterpenoids and phenols although alkaloids and steroids were not commonly found [10]. This in-vitro study using isolated rodent's uteri therefore provides preliminary evidence which could be used to further explore the in-vivo effect of this plant compound on uterine contraction.

\section{Competing interests}

Authors have nothing to disclose.

\section{Authors' contributions}

NS is the project leader who planned this study, was involved in data interpretation and prepared the manuscript for publication. Meanwhile, VNA conducted all experiments. Both authors have read and approved the manuscript.

\section{Acknowledgement}

This study was supported by the UMRG grant RG404/12 HTM, University of Malaya, Kuala Lumpur, Malaysia. We would like to thank Dr Norhaniza Aminudin from the Institute of Biological Sciences, Faculty of Science, University of Malaya for her continuous support. We would also like to thank Dr Charlie Hindmarch and Deirdre Hindmarch from Bristol University, United Kingdom for proof-reading the manuscript.

Received: 14 June 2013 Accepted: 5 December 2013

Published: 14 December 2013

\section{References}

1. Watcho P, Ngadjui E, Efouet PAN, Nguelefack TB, Kamanyi A: Evaluation of in- vitro uterotonic activities of fruits extracts of Ficus asperifolia in rats. Afr Health Sci 2010, 9(1):49-53.

2. Veale DJ, Havlik I, Oliver DW, Dekker TG: Pharmacological effects of Agapanthus africanus on the isolated rat uterus. J Ethnoparmacol 1999, 66(3):257-262

3. Datte J, Offoumou AM, Manda OM: Uterotonic effects of hydromethanolic extract of Parquetina nigrescens (Periplocaceae) on spontaneous contractile activity in the isolated myometrium of pregnant rats. J Ethnopharmacol 1996, 53:15-20.

4. Datte JY, Traore A, Offoumo AM, Ziegler A: Effects of leaf extract of Caesalpinia bonduc (Caesalpiniaceae) on the contractile activity of uterine smooth muscle of pregnant rats. J Ethnopharmacol 1998, 60:149-155.

5. Fasihuddin A, Rahman AH, Hasmah R: Medicinal Plants Used by Bajau Community in Sabah. Trends in Traditional Medicine Research The School of Pharmaceutical Sciences, University of Science Malaysia 1995:493-504.

6. Fasihudin A, Ghazali I: Medicinal plants used by Kadazandusun communities around crocker range. ASEAN Review of Biodiversity and Environtment Conservation (ARBEC) 2003:1-10. www.arbec.com.my/pdf/ art1janmar03.

7. Fuad WEM, Sulaiman SA, Islam MN, Wahab MSA, Syed MSJ: Evaluation of the teratogenicity of aqueous extract of Labisia pumila var. alata in rats. Malay J Med Sci 2005, 12(2):13-21.

8. Nikolajsen T, Nielsen F, Rasch V, Sørensen PH, Ismail F, Kristiansen U, Jäger AK: Uterine contraction induced by Tanzanian plants used to induce abortion J Ethnopharmacol 2011, 137(1):921-925.

9. Kuenzel J, Geisler K, Strahl O, Grundtner P, Beckmann MW, Dittrich B: Chelidonium majus and its effects on uterine contractility in a perfusion model. Eur J Obstet Gynecol Reprod Biol 2013, 169(2):213-217.

10. Broster JA: Amagquirha- Religion, magic and medicine in the Transkei. Cape Town: Via Afrika Limited; 1982. ISBN 10: 0799406406 / ISBN 13 9780799406405. 126 pages.

11. Starr F, Starr K, Loope L: Ficus deltoidea. United States Geological surveyBiology Resources Division, Haleakala Field Station, Maui, Hawaili 2003:120-300

12. Hassan DWE: Healing Herbs of Malaysia. Kuala Lumpur: Federal Land Development Agency; 2006.
13. Abkhan JK: Traditional healing of Ficus family in human health. eCAM 2009, 5:91-94.

14. Aminudin N, Sin CY, Chee ES, Nee Kl, Renxin L: Blood Glucose lowering effect of Ficus deltoidea Aqueous extract. Malay J Sci 2007, 26(1):73-78.

15. Sheldon W, Blum J, Durocher J, Winikoff B: Misoprostol for the prevention and treatment of postpartum hemorrhage. Expert Opin Investig Drugs 2012, 21(2):235-250.

16. Bafor EE, Lim CV, Rowan EG, Edrada-Ebel R: The leaves of Ficus exasperata Vahl (Moraceae) generates uterine active chemical constituents. J Ethnopharmacol 2013, 145(3):803-812.

17. Bafor EE, Amogbai EKI, Ozolua RI: In vitro determination of the uterine stimulatory effect of the aqueous leaf extract of Ficus exasperata. J Ethnopharmacol 2010, 127(2):502-507.

18. Bafor EEOE, Ozolua RI: Oxytocin inhibiting effect of the aqueous leaf extract of Ficus exasperata (Moraceae) on the isolated rat uterus. Acta Pol Pharm 2011, 68(4):541-547.

19. Owolabi OJNZ, Falodun A, Ayinde BA, Nwako CN: Evaluation of tocolytic activity of ethanol extract of the stem bark of Ficus capensis Thunb: (Moraceae). Acta Pol Pharm 2009, 66(3):293-296.

20. Owolabi OJOE, Falodun A: Oxytocic effects of the aqueous leaf extract of Costus lucanusianus - family Costaceae on isolated non-pregnant rat uterus. Pak J Pharm Sci 2010, 23(2):207-211.

21. Oropeza MV, Monter HP, Tello TV, Ayuirre JAP, Campos MG: Anatomical differences in uterine sensitivity to prostaglandin $\mathrm{F} 2 \mathrm{a}$ and serotonin in non- pregnant rats. Eur J Pharmacol 2002, 446(1-3):161-166.

22. Bafor $E$, Sanni $U$ : Uterine contractile effects of the aqueous and ethanol leaf extract of Newbouldia laevis (Bignoniaceae) in vitro. Indian Journal Pharmaceutical Sciences 2009, 71(2):124-127.

23. Hay A, Wood S, Olson D, Slater DM: Labour is associated with decreased expression of the PGF2a receptor (PTGFR) and a novel PTGFR splice variant in human myometrium but not decidua. Mol Hum Reprod 2010, 16(10):752-760.

24. Abdalla FMF, Marostica E, Picarelli ZP, Abreu LC, Avelar MCW, Porto CS Effect of estrogen on muscarinic acetylcholine receptor expression in rat myometrium. Mol Cell Endocrinol 2004, 213(2):139-148.

25. Kobayashi MAM, Minami K, Moro M, Ajisawa Y, Inoue Y, Kawarabayashi T: Role of oxytocin in the initiation of term and preterm labor in rats: changes in oxytocin receptor density and plasma oxytocin concentration and the effect of an oxytocin antagonist, L-366,509. Am J Obstet Gynecol 1999, 180(3 Pt 1):621-627.

26. Kimura T, Takemura M, Nomura S, Nobunaga T, Kubota Y, Inoue T, Hashimoto K, Kumazawa I, Ito Y, Ohashi K, Koyama M, Azuma C, Kitamura Y, Saji F: Expression of oxytocin receptor in human pregnant myometrium. Endocrinology 1996, 137:780-785.

27. Lefebvre DL, Farookhi R, Giaid A, Neculcea J, Zingg HH: Uterine oxytocin gene expression: II. Induction by exogenous steroid administration. Endocrinology 1994, 134(6):2562-2566

28. BRODT-EPPLEY J, MYATT L: Prostaglandin receptors in lower segment myometrium during gestation and labor. Obstetrics \& Gynecology 1999, 93(1):89-93.

29. Cook JL, Shallow MC, Zaragoza DB, Anderson KI, Olson DM: Mouse placental prostaglandins are associated with uterine activation and the timing of birth. Biol Reprod 2003, 68(2):579-587.

30. Varol FG, Hadjiconstantinou M, Zuspan FP, Neff NH: Pharmacological characterization of the muscarinic receptors mediating phosphoinositide hydrolysis in rat myometrium. J Pharmacol Exp Ther 1989, 249:11-15.

31. Pennefather JN, Gillman TA, Michelson F: Muscarinic receptors in rat uterus. Eur J Pharmacol 1994, 262:297-300.

32. Munns $\mathrm{M}$, Pennefather JN: Pharmacological characterization of muscarinic receptors in the uterus of oestrogen-primed and pregnant rats. $\mathrm{Br} J$ Pharmacol 1998, 123:1639-1644.

33. Dong Y-L, Yallampalli C: Pregnancy and exogenous steroid treatments modulate the expression of relaxant EP2 and contractile FP receptors in the rat uterus. Biol Reprod 2000, 62(3):533-539.

34. Crankshaw DJ: Muscarinic cholinoceptors in the rabbit's myometrium: a study of the relationship between binding and response. Eur J Pharmacol 1984, 110:1-10.

35. Sanborn BM: Hormones and calcium: mechanisms controlling uterine smooth muscle contractile activity: The Litchfield Lecture. Exp Physiol 2001, 86(2):223-237. 
36. Grigsby PL, Sooranna SR, Adu-Amankwa B, Pitzer B, Brockman DE, Johnson MR, Myatt L: Regional expression of prostaglandin E2 and F2alpha Receptors in Human Myometrium, Amnion, and Choriodecidua with advancing gestation and labor. Biol Reprod 2006, 75(2):297-305.

37. Sanborn BM: Hormonal signaling and signal pathway crosstalk in the control of myometrial calcium dynamics. Semin Cell Dev Biol 2007, 18(3):305-314.

38. Müller A, Siemer J, Renner S, Hoffmann I, Beckmann MW, Dittrich R: Modulation of uterine contractility and peristalsis by oxytocin in estrogen-primed non-pregnant swine uteri. Eur J Med Res 2006, 11(4):157-162

39. Dittrich R, Mueller A, Oppelt PG, Hoffmann I, Beckmann MW, Maltaris T: Differences in muscarinic-receptor agonist-, oxytocin-, and prostaglandin-induced uterine contractions. Fertility and sterility 2009, 92(5):1694-1700.

40. López BA: Mechanisms of labour-biochemical aspects. BJOG 2003, 110(Suppl 20):39-45.

41. Watcho PNE, Alango Nkeng-Efouet P, Benoît Nguelefack T, Kamanyi A: Evaluation of In Vitro Uterotonic activities of fruit extracts of Ficus asperifolia in Rats. Evid Based Complement Alternat Med 2011. 783413. 7 pages doi:10.1093/ecam/nep221. Epub 2011 Mar 13.

42. Shmygol A, Gullam J, Blanks A, Thornton S: Multiple mechanisms involved in oxytocin-induced modulation of myometrial contractility. Acta Pharmacol Sin 2006, 27(7):827-832.

43. Thomas RL, Mistry R, Langmead CJ, Wood MD, Chaliss RAJ: G protein coupling and signalling pathway activation by M1 muscarinic acetylcholine receptor orthosteric and allosteric agonists. J Pharmacol Exp Ther 2008, 327(2):365-374.

44. Crescenzo VD, Fogarty KE, Zhuge R, Tuft RA, Lifshitz LM, Carmichael J, Bellve KD, Baker SP, Zissimopoulos S, Lai FA, Lemosand JR, Walsh JV: Dihydropyridine receptors and type I ryanodine receptors constitute the molecular machinery for voltage- induced Ca2+ release in nerve terminals. J Neurosci 2006, 26(29):7565-7574

45. Awumey EM, Bukoski RD: Cellular functions and fluxes of calcium. In Calcium in Human Health. Edited by Weaver CM, Heaney RP. Totowa, NJ: Humana Press Inc; 2006:13-35.

46. Arthur P, Taggart MJ, Mitchell BF: Oxytocin and parturition: a role for increased myometrial calcium and calcium sensitization? Front Biosci 2007, 12:619-633.

47. Lijuan W, Kupittayanant P, Chudapongse N, Wray S, Kupittayanant S: The Effects of Wild Ginger (Costus speciosus (Koen) Smith) Rhizome Extract and Diosgenin on Rat Uterine Contractions. Reprod Sci 2011, 18(6):516-524.

48. Promprom W, Kupittayanant P, Indrapichate K, Wray S, Kupittayanant S: The effects of pomegranate seed extract and $\beta$-Sitosterol on rat uterine contractions. Reprod Sci 2010, 17(3):288-296.

49. Kupittayanant S, Kupittayanant $P$, Suwannachat $C$ : Mechanisms of uterine contractility in laying hens. Anim Reprod Sci 2009, 115(1-4):215-224.

50. Tica AA, Dun EC, Tica OS, Gao X, Arterburn JB, Brailoiu GC, Oprea TI, Brailoiu E: $G$ protein-coupled estrogen receptor 1-mediated effects in the rat myometrium. Am J Physiol - Cell Physiol 2011, 301(5):C1262-C1269.

51. Choo CY, Sulong NY, Man F, Wong TW: Vitexin and isovitexin from the Leaves of Ficus deltoidea with in-vivo a-glucosidase inhibition. J Ethnopharmacol 2012, 142(3):776-781.

52. Omar MH, Mullen W, Crozier A: Identification of Proanthocyanidin Dimers and Trimers, Flavone C-Glycosides, and Antioxidants in Ficus deltoidea, a Malaysian herbal tea. J Agric Food Chem 2011, 59(4):1363-1369.

doi:10.1186/1472-6882-13-359

Cite this article as: Salleh and Ahmad: In-Vitro effect of Ficus deltoidea on the contraction of isolated rat's uteri is mediated via multiple receptors binding and is dependent on extracellular calcium. BMC Complementary and Alternative Medicine 2013 13:359.

\section{Submit your next manuscript to BioMed Central and take full advantage of:}

- Convenient online submission

- Thorough peer review

- No space constraints or color figure charges

- Immediate publication on acceptance

- Inclusion in PubMed, CAS, Scopus and Google Scholar

- Research which is freely available for redistribution

Submit your manuscript at www.biomedcentral.com/submit 